\title{
Character Education in the Prevention of School Violence and as a Method for Promoting Academic Achievement
}

\author{
Okullarda Şiddeti Engellemede ve Öğrenci Başarısını Să̆lamada \\ Kişilik Ĕ̈itimi
}

\begin{abstract}
Namık TOP*
Abstract: When violence occurs in schools, the tendency is to apply restrictive and stringent punishments. Recently, studies suggested that promoting safety and prosocial student characteristics may be a viable strategy to prevent school violence. In particular, character education may serve as a method of prevention of aggression in schools. This article will review the literature on character education and explore how character education programs could influence learning and achievement in schools and promote learning and achievement.
\end{abstract}

Keywords: Character education, violence, achievement, prevention

Özet: Okullarda şiddet çoğu zaman sınırlayıcı ve sert cezalarla kaşılanır. En son çalışmalar güvenlik ve prososyal öğrenci özelliklerini desteklemenin okuldaki şiddeti önlemede başarılı bir strateji olduğunu göstermektedir. Özellikle, kişilik eğitimi okullardaki şiddeti önlemede yararlı olabilir. Bu çalışma, kişilik eğitimi hakkındaki çalışmaları taramakta ve bu tarz ders programlarının öğrenme, olkul başarısı, olumlu öğrenci davranışı gibi istendik davranışlarla olan ilişkisini ortaya koymaktadır.

Anahtar Sözcükler: Kişilik eğitimi, şiddet, başarı, önleme

Character education is both an old and a new topic. It is old, because, dating back to at least to the classical Greeks, societies have always recognized a great need to shape or guide the development of the character of their youth (Berkowitz \& Hoppe, 2009). However, formal or systematic research on this topic is relatively new. This article aims to illustrate how character education could contribute to student's learning and achievement. This article will briefly review the history of character education programs in the United States before discussing how character education could serve in the prevention of school violence while promoting academic achievement. This article concludes with recommendations for implementing character education programs in schools.

\section{Brief review of the History of Character Education}

The debate among ethic theorists over moral and character education in the United State dates back to colonial America (Glanzer \& Milson, 2006). Once considered as part of religious teaching, moral and character education programs had to be changed when states began passing laws in the early 1800s that separated issues of church and state. Thus, the educational system developed nonsectarian public school policies (Glanzer \& Milson, 2006), and character education was adopted by public schools in Massachusetts with the purpose of increasing

\footnotetext{
*PhD. Candidate, Texas A\&M University, namk1985@neo.tamu.edu
} 
literacy among children.

The Bible was used as part of the curriculum throughout the $17^{\text {th }}$ and $18^{\text {th }}$ centuries, and was then preceded by the texts written by William McGuffey. These texts were used to teach children to develop virtues such as honesty, courage, and kindness. During the $20^{\text {th }}$ century, however, there was a declined in the use of these texts in public schools in America due to pluralism and the philosophy of moral relativism. At the start of the $21^{\text {st }}$ century, American educators have increasing returned to and focused upon character education in schools and there has been various sources of grants funding to facilitate research in this field (Vardin A. Patricia Montessori Life, spring 2003).

\section{Definitions of Character Education}

Character education is an umbrella term that has historically included a wide range of components, such as traditional character education, the caring approach, and the developmental approach. The goal of character education is to teach children to consider and behave in ethical ways. Traditional character education has emphasized virtues and the magnitude of ethical issues. Secondly, the caring approach underscores the significance of identifying and improving caring relationships and infusing caring, relational, and social-emotional themes into school curricula (Howard, Berkowitz, \& Schaeffer, 2004). Third, the developmental approach stresses that decision-making and social action are important; theorists who ascribe to this approach strongly advocate the power of student participation in creating a moral classroom and a larger moral community (Cohen, 2006). Ontario's Premier, Dalton McGuinty, defines character education as, "the deliberate effort to develop virtues that are good for the individual and good for society" (McGuinty, 2003, 15). Character eduction is sometimes defined as an approach that is comprehensive in fostering the moral development of students (Berkowitz, Marvin, \& Bier, 2005). For decades, character education was inclined to focus on the importance of good character and values such as honesty, respect, friendship, and caring (Cohen, 2006). Thomas Likona (1991), a developmental psychologist, defined the goal of character education as knowing the good, desiring the good, and doing the good.

\section{Purpose of the Article}

This review article explores whether character education has an impact on preventing school violence through the virtues that it provides, and whether character education influences the achievement of children in schools. Character education has been an asset in prevention-based strategies. Prevention education is one key in addressing the issue of school violence (Miller, Kraus, \& Veltkamp, 2008). It has been posited that students need character education in their school curricular programs in order to create safe and effective academic learning environments (Colorado State Department of Education, Denver, 2000; Ediger, 1998; Marschall \& Mckee, 2002; Robelen, 2001). In addition, researchers have found that moral education is associated with lower levels of violence. For instance, it has been postulated by Patricia A. Vardin that a proliferation of chicanery in government and business, degradation in media, and a dramatic increase in violent crime in schools clearly reveal serious moral decline in the United States (Vardin A. Patricia Montessori Life, spring 2003). This article aims to address these questions.

\section{Research Questions}

1. Does character education have an impact on preventing school violence through the virtues that it teaches?

2. Does character education influence the achievement of children in schools? 


\section{DATA and RESULTS}

\section{What is Meant by School Violence?}

Violence is generally defined as an intentional structure of behavior in which one person threatens, attempts to damage, or does harm another person. Aggression is generally defined as a form of low-level violence that includes verbal, physical, or gestural behavior that is intended to cause minor physical harm, psychological distress, intimidation, or to induce fear in another (Greene, 2005). What is school violence and what are its consequences? In terms of lawful responsibility, school violence is the violence that occurs on school grounds, on school-supported transportation, and at school-sponsored events. Nevertheless, violence committed on school grounds often derives from conflicts reflected in the society. Thus, the lines are blurred between school and community violence and suggest that school staff should be cognizant of the community and the issues within which a school is positioned. School violence is a community or societal issue (Furlong \& Morrison, 2000), and members of the society have good reason to take a vested interest in school-based violence prevention initiatives.

\section{Costs of School Violence}

School violence is costly at both individual and societal levels. Costs to the victims are both physical and psychological; including threatened or damage to one's mental health (e.g., depressive symptoms), self identity (e.g., self-worth and self esteem), and ability or desire to learn (Clayton, Ballif-Spanvill, \& Hunsaker, 2001). One serious threat to school safety include having unauthorized weapons (e.g., knives or firearms) on school grounds. Weapon carrying has been associated with fighting, vandalism, and heavy drinking (Durant et al., 1997). When school safety is compromised, surveys indicate that students and teachers feel insecure at school and many avoid being at school for their own protection which then compromises school engagement and learning (Elliott, Hamburg, \& Williams, 1998).

\section{Methods of Reducing School Violence}

Back in 1997, over two-thirds of secondary schools had already implemented some form of violence prevention program or were preparing to do so (Price, \& Everett, 1997). These methods have included punishment, health education, and random weapons searches (Farrington, 1996).

1. Punishment: Expulsion and criminalization are the chief methods for dealing with school violence and weapons possession. Government polices at all levels reflect this punitive, legalistic approach to violence prevention (Elliott, Hamburg, \& Williams, 1998).

2. Health Education: Educational programs have been implemented with the goal to prevent violence and include enhancing children's social and cognitive functions, fostering prosaic behavior, and improving parental behavior. Many of these programs have had a favorable influence on aggression and antisocial behavior (Samples, \& Aber, 1998).

One of the most significant educational programs is character education. For example, The California Department of Education supports incorporating character education into a standardsbased educational system in a variety of ways such as providing resources to build and develop character in youth; supports the core values of trustworthiness, respect, responsibility, fairness, caring and citizenship. The California Department of Education, underscores that character education is a trait of effective schools:

Effective schools seek to develop and reinforce character traits, such as caring, citizenship, fairness, respect, responsibility, and trustworthiness, through a systematic approach that includes adult modeling, curriculum integration, a positive school climate, and access to comprehensive guidance and counseling services (Elementary Makes the Grade! CDE, 1999). 
3. Random or Targeted Weapons Searches: Handheld metal detectors are increasingly used to carry out random or targeted weapons searches in major public school systems. In some places in America, it seemed that there had been a significant reduction in weapons-related events; however, it was later discovered that students had learned the routine days when the metal detectors would not be used (Muir, 1992).

\section{The Effects of Character Education on Academic Achievement}

Studies have also found that character education helps to increase academic achievement (Elias, Zins, Weissberg et al., 1997). Studies have acknowledged many social and academic attitudes associated with enhanced student success (Benninga, Berkowitz, Kuehn, \& Smith, 2003). Critical thinking skills underlie much of academic achievement (Esquith, 2003), and according to Brooks (2002), the very skills needed for academic achievement (e.g., endurance, decision-making, problem solving, and critical thinking ) are fundamental principles entrenched in character education. Character education asserts that non-test related academic improvements are also made in consequence of a character education program. Students attending schools using a character education program called the Child Development Program showed more motivation to learn and possessed closer ties to their school than students who attended schools not implementing the Child Development Program (Benninga, et al., 2003). Students attending elementary schools that used the Character Counts program completed their assignments more regularly and with increased academic fidelity (e.g., less cheating) than students who did not attend such schools (Benninga, et al., 2003).

In order to understand character education it is imperative to understand the characteristics of the students. The schools that are strong academically and sturdy in building accomplished students are characterized by five main characteristics indentified by Elias, Zins, Weissberg et al., (1997):

1. They have a school climate articulating specific themes, character elements, and/or values

2. They have explicit instruction in social-emotional skills

3. They have explicit instruction in health-promotion and problem prevention skills

4. They have systems to enhance coping skills and social support for transitions, crises, and resolving conflicts

5. They have widespread, systematic opportunities for positive, contributory service.

After considering these traits one can conclude that students attending schools performing character education programs feel respected and valued which results in reduced non-attendance (Colgan, 2003). Reduced absenteeism, produced by the increased desire to attend to school, could be translated into achievement gains (Colgan, 2003). These factors, taken together, make for more classroom instructional time and an enhanced learning environment.

\section{Discussion}

As emphasized previously, tremendous progress has been made over the past two decades in establishing effective school-based violence prevention programs. Nevertheless, programs designed to decrease violence in schools have largely focused on reducing student-to-student aggressive behavior through school-based curricular programs (SBCPs), essentially ignoring interpersonal relationships between students and adults in schools, student bonding to schools, disproportionalities in the application of student discipline, and related organizational factors that contribute to a school is climate. Punishment, education, and weapon searches are some of the attempts to reduce school violence.

After considering several vantage points, it is the conclusion of this article that character education is a stellar attempt to reduce school violence and for increasing academic achievement. Educators should emphasize character development, as it is a culmination of a strong 
union of streams of evidence about factors that influence learning. According to Nucci and Narvaez (2008), moral and character education should be considered by educators as being congruent with learning individual values and in identity formation.

Character education has several positive outcomes that address the various needs of schools and communities. For example, it includes values such as tolerance, humility, modesty, and trustworthiness. Moreover, it is emphasized that cheating is a negative characteristic for every student. That is, every student should not engage in or condone cheating. Thus, it is stressed that academic learning and performance is linked to social-emotional skill and character development. These studies have only provided further evidence of the role of social and emotional factors in academic accomplishments (Kusche, \& Greenberg, 2006). These studies support the notion that every educator should take character education into account.

\section{How Could Character Education be Applied Toward Prevention?}

Character education may incorporate some local and state programs to help students increase achievement by developing their behaviors not just in the schools, but also in contexts outside of schools. One program called "Your Environment Education Program" is recommended by Starr (1999). According to this program, each week a word is chosen such as tolerance and honesty, to be discussed in the class. At least 10-15 minutes are allocated for these discussions. These discussions are meant to facilitate the comprehension of the meaning of the value by illustrating real-life implications, motivational quotes, and recommending some beneficial assignments for students to complete. All of these elements enhance students' deep understanding of the word and its value in their daily lives. This program also encourages parents to help their children by providing some books containing the word for that week. Parents are also encouraged to stress the meaning of the word at home by incorporating it into daily activities that families do together. Starr (1999) states that the community the Your Environment Education has been successfully implemented in the community in Pittsburg through program media outlets, local business sponsorships as well as the mayor's office to promote the importance of character education.

While character education appears to have positive effects on youth's behavioral and academic outcomes, there may also be negative implications in not employing character education in schools. For example, evidence indicates that punishment or incarcerating large numbers of young people for prolonged periods is ineffective and counterproductive (Wilson, 1994). A major problem with using targeted weapons searches in schools is that they implicitly stigmatize those students who are screened as potentially dangerous. The sudden and unexpected arrival of security personnel with metal detectors is also intimidating, anxiety provoking, and disruptive to learning. Serious conflicts also have a tendency to erupt suddenly and escalate before mediation efforts can be initiated. Therefore, as long as guns and other weapons can be brought freely into schools, educational approaches alone cannot be expected to solve the problem.

\section{Recommendations}

Based on the information reviewed in the article several recommendations are provided to facilitate the implementation of character education in schools as a method to reduce school violence and improve the school climate for learning. First, teachers, administrators and school psychologists should be provided with extensive and effective training concerning children and youth's development. When the character education program is implemented, teachers should be aware of how they interact with their students. For example, rather than giving commands to students so they would avoid misbehavior or making mistakes, teachers should engage students to critically reflect upon the consequences of their behaviors and whether or not they are willing to accept these consequences. In other words, teachers should encourage students to be personally 
responsible. Further, schools should offer students access to character education as a prevention or intervention strategy before misbehavior or problems occur. Character education could help foster the student's empathy, prosocial skills and social competencies that have been related to academic learning and achievement. Lastly, character education curriculum could be supported through media (e.g., graphics or cartoons) that serve to powerfully engage and remind students of the learning objectives of the curriculum.

\section{REFERENCES}

Benninga, J., Berkowitz, M., Kuehn, P., \& Smith, K. (2003). The relationship of character education implementation and academic achievement in elementary schools. Retrieved May 9, 2006, from the ProQuest database.

Berkowitz, M. W., \& Bier M. C. (2005). Character education parents as parents. Association for Supervision and Curriculum Development, 64-69.

Berkowitz, M. W., \& Hoppe, Mary Anne (2009). Character education and gifted children, High Ability Studies, 20(2), 131-142

Brooks, B. (2002). Increasing test scores and character education: The natural connection. Retrieved May 2, 2006, from http://www.youngpeoplespress.com/Testpaper.pdf.

Cohen, J (2006). Social, emotional, ethical, and academic education: Creating a climate for learning, participation in democracy, and well-being. Harvard Educational Review, 76(2), 201-237

Colorado State Department of Education, Denver. (2000). Shaping the future through character education: Colorado state conference on character education. (ERIC Document Reproduction Service No. ED468627).

Clayton, C, Ballif-Spanvill, B. L., \& Hunsaker M. D. (2001). Preventing violence and teaching peace: A review of promising and effective antiviolence, conflict-resolution, and peace programs for elementary school children. Birmingham Young University, Women's Research Institute

Durant, R. H., Kahn, J., Beckford, P. H., \& Woods, E. R. (1997). The association of weapon carrying and fighting on school property and other health risk and problem behaviors among high school students. Archives of Pediatric and Adolescent Medicine, 151, 360-366.

Elementary Makes the Grade! CDE, 1999, http://www.cde.ca.gov/ci/gs/em/emgsummary.asp

Elias, M. J., Zins, J. E., Weissberg, R. P., Frey, K. S., Greenberg, M. T., Haynes, N. M., Kessler, R., Schwab-Stone, M. E., \& Shriver, T. P. (1997). Promoting social and emotional learning: Guidelines for educators. Alexandria, VA: Association for Supervision and Curriculum Development.

Elliott, D. S., B. A. Hamburg, \& K. R. Williams, eds.(1998). Violence in American schools: A new perspective. New York: Cambridge University Press.

Esquith, R. (2003). There are no shortcuts. New York, Pantheon Books.

Farrington, D. P. (1996). Understanding and preventing juvenile youth crime. York, U.K., York Publishing.

Furlong, M., \& Morrison, G. (2000). The school in school violence: Definitions and facts. Journal of Emotional and Behavioral Disorders, 812, 71-82.

Glanzer, P. L., \& Milson, A. J. (2006). Legislating the good: A survey and evaluation of character education laws in the United States. Educational Policy, 20(3), 525.

Greene, M. B. (2005). Reducing violence and aggression in schools. Trauma. Violence, \& Abuse, 6(3), 236-253.

Howard, R, W., Berkowitz, M. W., \& Schaeffer, E. F. (2004). Politics of character education. Educational Policy, 18(1), 188-215.

Kusche, C., \& Greenberg, M. (2006). Brain development and social-emotional learning: An introduction for educators. In M. J. Elias \& H. A. Arnold (Eds.), The educator's guide to emotional intelligence and academic achievement:Social-emotional learning in the classroom. Thousand Oaks, CA: Corwin Press.

Lickona, T. (1991). Educating for character: How our schools can teach respect and responsibility. New York: Bantam Books. 
McGuinty, D. (2003). Character education: A key part of the Ontario Liberal Plan. Orbit, 33(2), 15.

Miller, T. W., Kraus, R. F., \& Veltkamp, L. J., (2008) Character education as a prevention strategy for school-related violence. Ed. T. W. Miller. In School Violence and Primary Prevention, 377-390.

Muir, E. (1992). School Staff Victimization: Monitoring the Trends. School Safety, Fall, 4-6.

Nucci, L., \& Narvaez, D. (Eds.). (2008). Handbook of moral and character education. New York: Taylor $\&$ Francis.

Price, J. H., \& S. A. Everett. (1997). A national assessment of secondary school principals perceptions of violence in schools. Health Education \& Behavior, 24, 218-229.

Samples, F., \& L. Aber. (1998). Evaluations of school-based violence prevention programs. In D. S. Elliot, B. A. Hamburg, \& K. R. Williams (Eds.), Violence in American Schools: A new perspective. New York: Cambridge University Press.

Starr, L. (1999). Is character education the answer? Retrieved August 1, 2008 from http://www.educationworld.com/a issues/issues047.shtml.

Vardin A Patricia Montessori Life, (Spring 2003). Character education in America. ProQuest Education Journals, 15(2), 32

Wilson, J. Q. (1994). Just take away the guns. New York Times Magazine, 20 March, 46-47. 